\title{
IMPLEMENTING THE PRINCIPLES OF EDUCATIONAL PSYCHOLOGY TO CREATE EFFECTIVE LEARNING
}

\author{
Dewi Purnama Sari ${ }^{1}$ \\ dewipurnamasari@iaincurup.ac.id
}

\begin{abstract}
This study aimed to describe the implementation of the principles of educational psychology in creating effective learning. This study used a qualitative approach with research informants consisting of the principal, viceprincipal and teachers of SDIT Rabbi Radhiyya of Curup. The total was nine informants. Research data were collected using non-participant observation, and unstructured interviews and triangulations of techniques and sources confirmed the data's validity - the data analysis in three stages: data reduction, data presentation, and concluding. The findings indicated that educational psychology principles were implemented in the teaching and learning at SDIT Rabbi Rhadiyya Curup, stimulating joy in learning, showing warm welcome, promoting rewards and developing fair competition are encouraged throughout the process.
\end{abstract}

Keywords: Principles, Educational, Psychology, effective learning

\begin{abstract}
Abstrak: Penelitian ini bertujuan untuk menguraikan tentang implementasi prinsip-prinsip psikologi pendidikan dalam menciptakan pembelajaran yang efektif. Penelitian ini menggunakan pendekatan kualitatif dengan informan penelitian kepala sekolah, wakil kepala sekolah dan guru SDIT Rabbi Radhiyya Curup berjumlah 9. Data penelitian dikumpulkan dengan observasi non partisipan dan wawancara tidka struktur, kemudian dicek kebsahannya dengan triangulasi teknik dan sumber. Data dinalisis melalui tiga tahap, yaitu reduksi data, penyajian data dan menarik kesimpulan. Hasil penelitian menunjukkan bahwa beberapa prinsip psikologi pendidikan yang diterapkan dalam pembelajaran di SDIT Rabbi Radhiyya Curup adalah menciptakan kondisi yang menyenangkan dalam pembelajaran, menerima siswa dengan hangat dan terbuka, memberikan penghargaan kepada siswa yang berprestesi dan menciptakan kompetisi yang kondusif.
\end{abstract}

Kata kunci: Prinsip, Psikologi Pendidikan, pembelajaran efektif

\section{Introduction}

From a psychological standpoint, education is a positive change that manifests itself in the form of a process and an outcome or product (Santrock, 2021). Education as a process includes various activities that aid in developing individual potential, the development of social life, and the transmission of religious habits, norms, values, language, and beliefs from one generation to the next generation (Achruh, 2018).

${ }^{1}$ Institut Agama Islam Negeri (IAIN) Curup, Indonesia 
SYAIKHUNA: Jurnal Pendidikan dan Pranata Islam STAI Syichona Moh. Cholil Bangkalan p-ISSN:2086-9088, e-ISSN: 2623-0054

DOI: https://doi.org/10.36835/syaikhuna.v12i2.4769

Individuals are encouraged to think, behave, and act more positively as a result of the educational process in order to meet individual needs while also bringing prosperity to the group (Al Farizi, t.t.). Education, as a product, includes a variety of changes that occur in individuals as the results of learning processes (Alice \& Crow, 1990). These modifications take the form of learning experiences in cognitive, affective, and psychomotor domains (Alice \& Crow, 1990; Sabri, 1996).

Intrinsically, psychology is a scientific study of human behaviour and mental processes (Perbowosari dkk., 2020). Educational psychology is a branch that focuses on studies of effective teaching and learning in the educational setting (Rahmat, 2021). According to the Encyclopedia Americana, "educational psychology is concerned with discovering and implementing principles and techniques that promote efficiency in instructions" (De Kay, 1968). Various studies show that the learning climate (Purwanto, 2014), which includes the nature, attitude, personality, social condition, physical condition, mental condition, values adopted, and skills possessed, has a strong influence on efficient learning (Marbun, 2018). Experts in educational psychology attempt to empirically investigate the learning climate in the hope of assisting teachers in implementing an effective and efficient learning process (Thalib, 2017). Educational psychology provides an overview and explanation of a person's learning experiences and various factors influencing the learning process (Nurhayati, 2018). Teachers must be fully aware of the conditions that can disrupt the learning process in order for learning to take place effectively.

The question arises as to why teachers should study educational psychology. Learning, as previously stated, is linked to various interactions between teachers and students. Learning is also more than just passing on knowledge to others (Syaharuddin, 2020). The use of multiple strategies is required for effective teaching (Simarmata dkk., 2019). Because teaching deals with highly complex issues, there is no single, effective way to carry out learning processes in all circumstances (Sutarto et al., 2020). Teachers must master various strategies, approaches, learning models, and methods and apply them flexibly (Sidiq \& Lukitoyo, 2019). To this end, two things require professional knowledge alongside expertise and commitment in tandem with motivation.

There is no single good learning formula, but the characteristics of an exceptional teacher will be evident, like his intentionality (Dhofir, 2018). Intentionality 
SYAIKHUNA: Jurnal Pendidikan dan Pranata Islam STAI Syichona Moh. Cholil Bangkalan p-ISSN:2086-9088, e-ISSN: 2623-0054

DOI: https://doi.org/10.36835/syaikhuna.v12i2.4769

is defined as doing something with purpose and according to a well-thought-out plan (Slavin, 2011). Teachers who are intentional about carrying out learning have clear goals, plan learning based on the goals to be achieved, carry out activities, and make various decisions that orient toward achieving learning outcomes by learning objectives (Desilawasi \& Amrizal, 2014). Intentional teachers recognize that good learning does not happen by chance but rather by setting goals, planning, and implementing activities to achieve those goals (Sufiati \& Afifah, 2019).

Teaching is more than just transferring knowledge; it also assists students in becoming learners (Hall, 2017). Teachers can use three indicators to determine whether their students have become learners: (1) students are happy with what they are learning, (2) students are not bored and always talk about lessons, and (3) students show higher achievements (Hall, 2017). Students' abilities to perform at a higher level can be physical, social, creative, or intellectual. Thus, the teachers' success is highly dependent on how students learn the concepts taught by the teachers.

Teachers must also have pedagogical knowledge of teaching methods, knowledge of children, knowledge of the subject matter, classroom management and organization knowledge, and knowledge of themselves and others (Cruickshank, 2014).

The primary goal of learning is to provide students with information or knowledge, skills, values, and teacher attitudes and apply psychological principles to learning practices (Slavin, 2011). Teachers who study and apply educational psychology in learning can more effectively convey information, knowledge, and skills and instil values and attitudes through habituation, examples, and appropriate learning strategies.

The purpose of this research is to describe, in detail, the application of educational psychology principles to create effective learning at SDIT Rabbi Radhiyya of Curup. This research expects to provide information and assist teachers in finding solutions to create effective learning.

\section{Method}

This study applied a qualitative research method. Qualitative research is a study that seeks to reveal phenomena in depth by the existing facts, then described systematically using words and data (Creawell, 2015; Meleong, 2014). The qualitative 
SYAIKHUNA: Jurnal Pendidikan dan Pranata Islam STAI Syichona Moh. Cholil Bangkalan

p-ISSN:2086-9088, e-ISSN: 2623-0054

DOI: https://doi.org/10.36835/syaikhuna.v12i2.4769

method was used because this study sought to describe in-depth and existing reactions for applying Educational Psychology principles in learning.

This study was conducted at SDIT Rabbi Radhiyya of Curup in 2018 with nine informants, including teachers, the principal, and vice-principal. The data collection technique used was a non-participant observation, as observed. The researcher only observes phenomena in the field and is not directly involved in what the observed object is doing (Sugiono, 2018). Furthermore, the researcher conducted unstructured interviews as a type of interview. The researcher relies on an interview protocol composed of the primary thoughts about the object asked when conducting interviews (Sugiono, 2018).

The Miles and Hubermen's model of data analysis technique was adopted, and it consisted of three stages: data reduction, data presentation, and conclusion drawing (Craswell, 2016). Triangulations of techniques and sources were used to test the data's validity. Technical triangulation is a data validity test that involves a combination of several data collection techniques, in this case, non-participant observation and semistructured interviews (Sugiono, 2018). Source triangulation is a method of testing the data's validity by cross-checking between one informant and another (Sugiono, 2018).

\section{Result and Discussion}

\section{Result}

SDIT Rabbi Radhiyya is an Islam-based elementary school that combines the Education Office Curriculum and the Ministry of Religion Curriculum. SDIT Rabbi Radhiyya is an Islamic-based elementary school that has won numerous awards at the district, provincial, and national levels, making it one of the most popular schools in Curup, Rejang Lebong Regency of Bengkulu Province.

SDIT Rabbi Radhiyya has used Educational Psychology principles in the implementations of teaching and learning, including:

1. Creating conditions triggering students' comfort to stay around the school environment The school's efforts to make students happy to be in the school environment created a safe, comfortable, and friendly school culture. Teachers and 
school personnel held the key to creating a safe, comfortable, and friendly school culture. The Principal, Eko Cahya Ningsih, explained:

Teachers and school personnel must meet specific criteria, including being friendly, gentle, and affectionate. Like the preceding, in accepting prospective teachers and school personnel, they consider the aspects of their personality and educational background specifications. A friendly, gentle demeanour and a fondness for children are two aspects of personality that considers.

According to observations, a friendly atmosphere could see when students arrive at school in the morning. Every morning, the principal and several teachers stood at the school gate to greet new students. Students greeted the teachers, who had greeted them at the school gate, one by one. The students appeared to be excited because several teachers greeted their arrival at school at the school gate. Psychologically, students' presence at school was accepted and desired when some teachers greeted them at the gate. This type of treatment gave students the impression that the school environment was safe and comfortable.

The cases of student fights and bullying rarely occurred at this school. Rajab Efendi, the Student Representative, explained:

Students are encouraged to love their classmates' friends. A "gift exchange" event is held every semester of each class to foster intimacy among classmates. Each student was asked to bring a gift to school under certain conditions, and then they exchanged gifts with their classmates in class. This activity creates a psychological feeling of acceptance, care, and appreciation for students. They get to know each other and exchange gifts based on their personalities, desires, and needs. As a result, they feel accepted, cared for, and valued by their peers.

2. Coping with students who violated the school's rules

According to Rajab Efendi, the Student Representative, several school rules were frequently violated by students but did not include serious violations; these regulations include the following:

The rules that are often violated include bringing more pocket money than what is stipulated. This school does make rules about the maximum amount of pocket money that can be brought to school. From class I to class III, the maximum is IDR. 3,000, while for class IV to class VI, the maximum is IDR. 5,000. This rule trains students to be disciplined, not extravagant, and eat snacks as needed because students have brought lunch from home on average. In addition to bringing more pocket money than stipulated, the rule that is often violated is eating standing up. The attitude towards students who violate such school rules is to be given educational sanctions, for example throwing garbage, reciting the Qur'an, and memorizing the Qur'an. 
3. The basis of consideration for grouping students

This school used three types of student grouping: grouping students in class, grouping students in study groups, and grouping students in extracurricular activities.

Demis explained in an interview with the Curriculum Deputy as follows:

Each of these activities has a different set of criteria for grouping students. Aside from academic achievement, grouping students in class is based on attitudes/habits in making friends. Every new school year, students are organized into classes. This means that students in a new class make new friends every year. Academic achievement, student attitudes/habits, and student learning methods are the primary considerations for grouping students into study groups. Class teachers or subject teachers are typically in charge of this grouping.

Meanwhile, the basis for grouping students in extracurricular activities rested upon disclosing the instrument's talents and interests, students' choices, and interests. Ustazah Tati elaborated the following:

There are many extracurricular activities available at this school, and students are free to choose which ones they want to participate in each year. Except for grade I students, all students require to participate in Abacus extracurricular activities. This activity's purpose is to train numeracy skills and the balance of the left and right brains. When they reach class II, they are free to participate in whatever extracurricular activities they want.

4. Creating conditions triggering students' enthusiasm for learning

The study's findings also showed that teachers created learning environments that made students willing to learn. Ustaz Sujud elaborated the following:

To encourage students to enjoy learning in class, this school has rules requiring teachers to engage in fun, creative learning and provide daily monthly and semester rewards. It recommends that teachers actively involve students in their learning (applying active learning).

Ustazah Yetti said that students are also allowed to demonstrate, ask open questions, and express their opinions. In interactions with students, the teachers adopted a friendly, gentle, fair, or unfavourable demeanour. At this school, the slogan "Teachers are my friends" aimed to encourage students to interact with teachers, be open, and dare to ask the teachers any question to facilitate learning processes.

5. We are maintaining or improving students' behaviour.

This school always recognized students who exhibited good academic and nonacademic behaviours, such as extracurricular activities and daily behaviour. According to Ustaz Rajab Efendi, teachers provided feedback on the work the students had done 
as soon as possible in the academic field. Whatever the size of the assignment, it was assessed and graded as soon as possible. The student who performed the best on the assignment received a star sticker, which he wore on his shoulder or chest for the rest of the day. Oftentimes, teachers also rewarded students with small gifts such as pencils, pens, erasers, pencil sharpeners, notebooks, or money, in addition to star stickers. According to one teacher, even though the prize was small, the students felt thrilled because they received it directly from the teacher.

According to Ustazah Anggi, students who exhibited good behaviour were rewarded. Daily, the teachers observed which students helped other friends, did well on the scheduled duty, were disciplined, completed assignments quickly, submitted the Quran memorization first, Etc. Small prizes were also given to these students as rewards. One of the tahfidz teachers, Ustazah Yensi, stated that he once gave IDR. 1,000 to the first student to make a Qur'anic rote submission. This treatment motivated his friends to speed up their memorization and become the first students to deposit memorization further. Similarly, in extracurricular activities, in every semester, there was an inter-club competition. Each club's winner received a prize and was promoted to a competition representing the school.

6. Changing students' unwanted behaviour

If any students had not completed a particular material, the teacher immediately conducted remedial teaching (teaching improvements) individually and in groups. Students were given various exercises to help them master the material that had not yet been mastered. If a student did not want to do an assignment in class, the teacher took an individual approach, asking the student privately why they did not want to do it. As an English teacher, Ustazah Susi stated:

I once encountered a student who refused to complete the assignment that had been assigned to him. He even liked to draw. I inquired as to why he did not want to write. The student's reason was that what had been written was already in the book. I smiled back and asked the students to complete the picture correctly. When all of his classmates had turned in their assignments, I graded the student's picture and told him quietly that he had to complete the assignment the following week. The student nodded in agreement. He was ready to write and do assignments like the others the following week.

The teacher did not chastise students who liked drawing or making toys out of paper while studying. Students were always eager to demonstrate their inventiveness. To channel this creativity, the teacher allowed students to decorate their classroom by 
SYAIKHUNA: Jurnal Pendidikan dan Pranata Islam STAI Syichona Moh. Cholil Bangkalan p-ISSN:2086-9088, e-ISSN: 2623-0054

DOI: https://doi.org/10.36835/syaikhuna.v12i2.4769

displaying their works. Every semester, the school held a competition to select the most creative class based on this phenomenon. If some students liked chatting with others or disturbing others' activities while studying, they were usually summoned personally, given coaching in stages, and special training.

\section{Discussion}

According to the research findings, teachers' attitudes who accept, treat students with affection, and encourage students to excel are the critical aspects of children's development. According to Hurlock (2000), the essence of happiness is acceptance, affection, and achievement. Happiness is a pleasant sense of fulfilment that occurs when specific individual needs and expectations are met. As a result, to make students happy to be at school, this school focuses on one of the psychological aspects, namely instilling a sense of happiness in each student through acceptance, affection, and achievement. There is no reason for students to be afraid or lazy to go to school if they are happy to be there.

A close relationship is formed due to the teacher-student interaction that is based on affection (attachment). The resulting attachment is secure, and a secure attachment is the foundation of a positive relationship. A secure attachment and a positive relationship are the critical components of educational processes. Affection fosters a secure attachment, resulting in a positive relationship between teachers and students. Several studies in neurobiology have discovered that positive relationships can lead to positive emotions (Snyder dkk., 2011). Positive emotions can stimulate neocortical growth, increase hypothalamic-pituitary-adrenocortical stimulation of HPA hormones, and keep the left and right brains balanced to maximize brain function for learning (Porter \& Hernacki, 2011).

The attitude toward students who break the rules or exhibit undesirable behaviour is to impose educational sanctions such as taking out the trash, reciting the Qur'an or recitations, and memorizing the Qur'an. Applied behaviour analysts Paul Alberto and Anne Troutman, as cited in Santrock (2021), recommended a few steps which can be done to handle students' unwanted behaviour: using differential reinforcement, stopping the reinforcement (extinction), eliminating the desired stimulus, and presenting the unwanted stimulus (punishment). Differential 
SYAIKHUNA: Jurnal Pendidikan dan Pranata Islam STAI Syichona Moh. Cholil Bangkalan p-ISSN:2086-9088, e-ISSN: 2623-0054

DOI: https://doi.org/10.36835/syaikhuna.v12i2.4769

reinforcement occurs when a teacher reinforces more appropriate behaviours or are not in line with what the child is doing. A teacher, for example, may encourage a student to be polite rather than interrupting, to remain seated rather than running around in class, or to complete homework on time rather than being late. As a result, the teacher's first choice for reducing unwanted child behaviour should be in the form of differential reinforcement. Punishment should only be used as a last resort and should always be accompanied by information about appropriate behaviour for children. What was done above by the SDIT teacher Rabbi Radhiyya to reduce unwanted student behaviour was categorized as a form of differential reinforcement.

A constructivist approach involves students studying alone with their classmates, studying in groups of three or four students to study with their friends. Constructivism, as defined by Piaget as cited in Slavin (2011), is a view of cognitive development as a process in which children actively construct systems of understanding and understanding of reality through their experiences and interactions. According to Vygotsky as cited in Slavin (2011), learning occurs when children work in their zone of proximal development. Tasks in the proximal zone are those that a child cannot do alone but can do with the assistance of a more competent peer or adult. In other words, the zone of proximal development refers to tasks that a child has not yet learned but can learn at any time (Slavin, 2011).

During group discussions, the teacher guides each group to conclude the studied material; this is known as scaffolding in social learning. Responding entails providing a child with much support during the early stages of learning, then gradually decreasing support and asking the child to take on more responsibility as soon as possible (Slavin, 2011).

A cooperative learning strategy involves providing opportunities for students to study with their classmates or in groups of three or four students. Cooperative learning strategies are learning strategies that allow children to collaborate to help each other learn. Peers typically work in the zone of proximal development, frequently setting an example for other children. Cooperative learning strategies can also advance children's thinking (Sudarsana, 2018).

Students in the particular tahfidz program are asked to create their memorization targets. They are also asked to take the initiative to do muroja'ah 
SYAIKHUNA: Jurnal Pendidikan dan Pranata Islam STAI Syichona Moh. Cholil Bangkalan p-ISSN:2086-9088, e-ISSN: 2623-0054

DOI: https://doi.org/10.36835/syaikhuna.v12i2.4769

(repeating memorization with the teacher), which is known as self-regulation in social learning theory. Self-regulation, according to Bandura, is a person's ability to observe his behaviour, judge it based on his standards, and strengthen or punish himself. Students can be taught and reminded to use independence strategies in various contexts so that independence becomes a habit (Lesilolo, 2018). For example, students could be asked to set goals for the amount of time they need to study each night and track whether or not they meet those goals. Unfortunately, this approach has only been used in the particular tahfidz program, despite being used in other learning programs.

According to Skinnerians, giving small prizes such as star stickers, pencils, pens, erasers, pencil sharpeners, notebooks, or money for each achievement or good behaviour displayed by students is known as rewards. Skinnerians distinguish between reinforcers and rewards. According to Pavlov, a reinforcer is an unconditioned stimulus that strengthens any behaviour immediately before the reinforcing event. At the same time, rewards are thought to be only given or received for meritorious accomplishments, compensation for sacrifices or efforts (Hergenhahn \& Olson, 2015).

Giving rewards to students who exhibit desired behaviour motivates other students to do the same, while sanctioning students who exhibit unwanted behaviour causes other students not to do the same. This is an application of the observational learning model. Bandura defines observational learning as "learning that includes acquiring skills, strategies, and beliefs by observing other people." Individuals have vicarious abilities, which include learning by observing other people's behaviour and the consequences of that person's behaviour, also known as vicarious learning (Yanuardianto, 2019).

The application of discovery learning is to provide opportunities for students to experiment and observe science subjects. Discovery learning is a learning method that allows students to think in ways that will benefit their development (Ozdem-Yilmaz \& Bilican, 2020). Students must participate in the process of acquiring knowledge because knowledge is a process rather than a product. 
SYAIKHUNA: Jurnal Pendidikan dan Pranata Islam STAI Syichona Moh. Cholil Bangkalan p-ISSN:2086-9088, e-ISSN: 2623-0054

DOI: https://doi.org/10.36835/syaikhuna.v12i2.4769

\section{Conclusion}

Some of the principles of educational psychology that are implemented in learning at SDIT Rabbi Radhiyya Curup are educating with compassion, accepting students warmly and openly, encouraging students to excel, providing differential reinforcement, applying a constructivist approach, a scavenging system or scaffolding, cooperative learning strategies, self-directed learning, self-regulated learning, giving rewards or rewards and punishments, observational learning or vicarious learning, and discovery learning. The principles of educational psychology are beneficial for teachers in creating effective learning, thus enabling the achievement of maximum learning outcomes.

\section{REFERENCES}

Achruh, A. (2018). Perkembangan Ilmu Pengetahuan dan Landasan Sosial Budaya. Jurnal Inspiratif Pendidikan, 7(1), 23-32.

Al Farizi, M. A. (t.t.). Dinamika Kebudayaan pada Pendidikan.

Alice, C., \& Crow, L. D. (1990). Psikologi Pendidikan. Surabaya: PT. Bina Ilmu.

Anwar, A. S. (2020). Pengembangan Sikap Profesionalisme Guru Melalui Kinerja Guru pada Satuan Pendidikan MTs Negeri 1 Serang. Andragogi: Jurnal Pendidikan Islam dan Manajemen Pendidikan Islam, 2(1), 147-173. https://doi.org/10.36671/andragogi.v2i1.79

Anwar, M. (2018). Menjadi Guru Profesional. Prenada Media.

Arfani, L. (2018). Mengurai Hakikat Pendidikan, Belajar dan Pembelajaran. Pelita Bangsa Pelestari Pancasila, 11(2).

Craswell, J. W. (2016). Research Dseign: Pendekatan Kualitatif, Kuantitatif dan Campuran. Pustaka Pelajar.

Creawell, J. W. (2015). Penelitian Kualitatif dan Desain Riset: Memilih diantara Lima Pendekatan. Pustaka Pelajar.

Cruickshank, Donald. R. (2014). Perilaku Mengajar. Selemba Humanika.

De Kay, D. (1968). Encyclopedia Americana. The Journal of Library History (1966-1972), $3(3), 201-220$.

Desilawasi, D., \& Amrizal, A. (2014). Guru Profesional di Era Global. Jurnal Pengabdian Kepada Masyarakat, 20(77).

Dhofir, M. (2018). Karakter Guru Profesional. TARBAWI. Jurnal Studi Pendidikan Islami, $5(01)$.

Hall, Gene. E. (2017). Mengajar dengan Senang. I. 
SYAIKHUNA: Jurnal Pendidikan dan Pranata Islam STAI Syichona Moh. Cholil Bangkalan

p-ISSN:2086-9088, e-ISSN: 2623-0054

DOI: https://doi.org/10.36835/syaikhuna.v12i2.4769

Hamid, A. (2017). Guru Profesional. Al-Falah: Jurnal Ilmiah Keislaman dan Kemasyarakatan, 17(2), 274-285.

Hergenhahn, B., \& Olson, M. H. (2015). Theories of Learning. Kencana.

Hurlock, E. B. (2000). Psikologi Perkembangan Suatu Pendekatan Seanjang Rentang Kehidupan. Erlangga.

Iskandar, K. (2017). Profesionalisme guru dalam pendidikan Islam dan gambaran ideal seorang pendidik. JALIE; Journal of Applied Linguistics and Islamic Education, 1(1), 21-40.

Lesilolo, H. J. (2018). Penerapan Teori Belajar Sosial Albert Bandura dalam Proses Belajar Mengajar di Sekolah. KENOSIS: Jurnal Kajian Teologi, 4(2), 186-202. https://doi.org/10.37196/kenosis.v4i2.67

Marbun, S. M. (2018). Psikologi Pendidikan. Uwais Inspirasi Indonesia.

Meleong, L. J. (2014). Metodologi Penelitian Kualitatif. Remaja Rosdakarya.

Mukti, M. A. (2017). Profesionalisme Guru dalam Pembelajaran. AT-Ta'DIB: Jurnal Kependidikan dan Keagamaan, 1(1), 41-55.

Nurhayati, E. (2018). Psikologi Pendidikan Inovatif (Vol. 2). Pustaka Pelajar.

Ozdem-Yilmaz, Y., \& Bilican, K. (2020). Discovery Learning-Jerome Bruner. Dalam Science Education in Theory and Practice (hlm. 177-190). Springer.

Perbowosari, H., Wijoyo, H., \& Setyaningsih. (2020). Pengantar Psikologi Pendidikan. Penerbit Qiara Media.

Porter, B. D., \& Hernacki, M. (2011). Quantum Learning Membiasakan Belajar Nyaman dan Menyenangkan. Kaefa.

Purwanto, N. (2014). Psikologi pendidikan.

Rahma, U., \& Dara, Y. P. (2017). Psikologi Pendidikan: Aplikasi Teori di Indonesia. Universitas Brawijaya Press.

Rahmat, P. S. (2021). Psikologi pendidikan. Bumi Aksara.

Ria, D. R., \& Wahidy, A. (2020). Guru Kreatif di Era Society 5.0. Prosiding Seminar Nasional Program Pascasarjana Universitas PGRI Palembang.

Sabri, A. (1996). Psikologi pendidikan. Jakarta: Pedoman Ilmu Jaya.

Sakerebau, J. (2018). Memahami Peran Psikologi Pendidikan Bagi Pembelajaran. BIA': Jurnal Teologi dan Pendidikan Kristen Kontekstual, 1(1), 96-111.

Sanjaya, P. (2019). Peranan Psikologi Pendidikan Sebagai Kompetensi Dasar Pendidik dan Tenaga Kependidikan. Guna Widya: Jurnal Pendidikan Hindu, 4(2), 47-56.

Santrock, J. W. (2021). Psikologi pendidikan.

Sidiq, R., \& Lukitoyo, P. S. (2019). Strategi Belajar Mengajar Sejarah: Menjadi Guru Sukses. Yayasan Kita Menulis.

Simarmata, J., Iqbal, M., \& Nasution, I. N. (2019). Tren dan Aplikasi: Strategi dan Inovasi Dalam Pembelajaran. Denpasar: Jayapangus Press. 
SYAIKHUNA: Jurnal Pendidikan dan Pranata Islam STAI Syichona Moh. Cholil Bangkalan

p-ISSN:2086-9088, e-ISSN: 2623-0054

DOI: https://doi.org/10.36835/syaikhuna.v12i2.4769

Slavin, Robert. E. (2011). Psikologi Pendidikan Teori dan Praktik. Indek.

Snyder, C. R., Lopez, S. J., \& Pedrotti, J. T. (2011). Positive Psychology. Sage.

Sudarsana, I. K. (2018). Pengaruh Model Pembelajaran Kooperatif Terhadap Peningkatan Mutu Hasil Belajar Siswa. Jurnal Penjaminan Mutu, 4(1), 20-31. https://doi.org/10.25078/jpm.v4i1.395

Sufiati, V., \& Afifah, S. N. (2019). Peran perencanaan pembelajaran untuk performance mengajar guru pendidikan anak usia dini. Jurnal Pendidikan Anak, 8(1), 48-53.

Sugiono. (2018). Metode Penelitian Pendidikan: Pendekatan Kuantitatif, Kualitatif dan $R \mathcal{E}$ D. Alfabeta.

Sutarto, S., \& Sari, D. P. (2020). Characteristics of Professional Teacher: A Psychological Review of The Personality of Prophet Muhammad SAW. Psikis: Jurnal Psikologi Islami, 6(2), 164-177.

Sutarto, S., Sari, D. P., \& Fathurrochman, I. (2020). Teacher strategies in online learning to increase students' interest in learning during COVID-19 pandemic. Jurnal Konseling dan Pendidikan, 8(3), 129-137.

Syaharuddin, S. (2020). Menimbang Peran Teknologi dan Guru dalam Pembelajaran di Era COVID-19. Menimbang Peran Teknologi dan Guru dalam Pembelajaran di Era COVID-19.

Thalib, S. B. (2017). Psikologi pendidikan berbasis analisis empiris aplikatif. Prenada Media.

Wahyono, P., Husamah, H., \& Budi, A. S. (2020). Guru profesional di masa pandemi COVID-19: Review implementasi, tantangan, dan solusi pembelajaran daring. Jurnal Pendidikan Profesi Guru, 1(1), 51-65. https://doi.org/10.22219/jppg.v1i1.12462

Widodo, G. S., \& Rofiqoh, K. S. (2020). Pengembangan guru profesional menghadapi generasi alpha. Jurnal Ilmiah Pendidikan Citra Bakti, 7(1), 13-22.

Yanuardianto, E. (2019). Teori Kognitif Sosial Albert Bandura (Studi Kritis Dalam Menjawab Problem Pembelajaran di MI). Auladuna: Jurnal Prodi Pendidikan Guru Madrasah Ibtidaiyah, 1(2), 94-111. https:/ / doi.org/10.36835/au.v1i2.235 